DOI: https://doi.org/10.32353/khrife.2018.18

UDC 343.98

Prof. Dr A. Ivanović, Deputy Director of

Forensic Center Montenegro

E-mail: aleksandar.ivanovic@policija.me

\title{
ORGANIZATION OF FORENSIC LABORATORIES IN EUROPE WITH A WELDING TO WESTERN BALKAN COUNTRIES - PRACTICAL ASPECT
}

This paper gives an overview of the organizational positioning of forensic laboratories in the countries of Europe with a particular emphasis on the countries of the Western Balkans. This is because the region of the Western Balkans is relatively small in size and has a large number of countries, almost in all of which forensic laboratories are organized. As you can see from the paper, most forensic laboratories are organized in the interior ministries, that is in the police. Since this way of organizing the fulfilment of tasks on proving evidence in solving crimes causes procedural harassment, the very conclusion of the work is to give a proposal for their permission, which refers to the accreditation of forensic laboratories.

Keywords: forensic laboratory, police, accreditation.

Introduction. For the purpose of more efficient conduct of criminal investigations, it has long been a widely accepted approach that they must be based on scientific grounds. The application of methods of fundamental, natural sciences in the fight against crime contributes to greater effectiveness, objectivity and humanity of the fact-finding process, when dealing with criminal offenses. At the beginning of the twentieth century, after the formation of virtually the first forensic laboratories in the world, the main burden of investigation (investigatory actions and investigations) is carried out within the interior ministries ${ }^{1}$. This required

1 The first Institute of Scientific Police was formed in Lausanne in 1909. After Lausanne, the criminal-technical institutions were formed in Graz (in 1912, the Institute founded by Hans Gross, a well-known criminalist of that time, and the author of the first book in the field of criminal technique, the Handbook for Investigative Judges), then in Vienna (in 1923, the Institute of Criminal Law and Criminology, and two years later, the Institute of Criminalistic Examination). In Germany, after the Prussian War, the Prussian Police Institute was formed, which had an educational and research function, among other things in the field of criminal-technical science. In the Federal Republic of Germany (at that time the term West Germany was used) in 1951 the Federal Criminal Investigation Institute in Wiesbaden (Province of Hessen) was established. This institute, which is organized organically in the Federal Criminal Police of Germany, is valid for the personnel and materially-equipped institution of its kind in Europe. In the former USSR, in 1919, the first office of the Court Expertise was established, not long after 1922, the Scientific and Technical Department was formed at the NKVD. After the Second World War in Moscow in 1946, the Federal Research Institute was established. This institute was staffed and technically equipped for the most complex criminal-technical research, testing and analysis. In the United States, the first police laboratory was founded in 1923 in Los Angeles. Thereafter, similar criminal-technical institutions are established in all US states, and a central laboratory is established at the FBI in 1932. However, in addition to the aforemen-

(C) Ivanović A., 2018 
that within the interior ministries, that is within the police, organizational units should be formed to deal with the forensic investigation (expertize) of material traces from the scene of the criminal offense.

Organization of Forensic Affairs in the countries of Europe. Forensic jobs in the countries of Europe are performed in state institutions that are most often organized organically in the police (Ministry of Internal Affairs) and/or in the Ministry of Justice, and are rarely independent state institutions. In some European countries (usually large-populated countries), forensic institutions exist in both the police (the interior ministry) and the justice ministry. Table 1 gives an overview of the organizational positioning of forensic institutions in the European countries.

Table 1

Presentation of the positioning organization of forensic institutions in the European countries

\begin{tabular}{|c|c|c|}
\hline $\begin{array}{l}\text { The countries of Europe } \\
\text { where forensic institutions } \\
\text { are part of the Ministry of } \\
\text { Internal Affairs (Police) }\end{array}$ & $\begin{array}{c}\text { The countries of Europe } \\
\text { where forensic } \\
\text { institutions are part of } \\
\text { the Ministry of Justice }\end{array}$ & $\begin{array}{l}\text { The countries of Europe } \\
\text { where forensic institutions } \\
\text { are part of other state } \\
\text { organizations }\end{array}$ \\
\hline $\begin{array}{l}\text { 1. Albania } \\
\text { 2. Austria } \\
\text { 3. Bosnia and } \\
\text { Herzegovina } \\
\text { 4. Bulgaria } \\
\text { 5. Montenegro } \\
\text { 6. Denmark } \\
\text { 7. Finland } \\
\text { 8. France } \\
\text { 9. Greece } \\
\text { 10. Georgia } \\
\text { 11. Croatia } \\
\text { 12. Italy } \\
\text { 13. Cyprus } \\
\text { 14. Latvia } \\
\text { 15. Lithuania } \\
\text { 16. Hungary }\end{array}$ & $\begin{array}{l}\text { 1. Azerbaijan } \\
\text { 2. Estonia } \\
\text { 3. The Netherlands } \\
\text { 4. Ireland } \\
\text { 5. Lithuania } \\
\text { 6. Russian Federation } \\
\text { 7. Ukraine }\end{array}$ & $\begin{array}{l}\text { 1. Armenia (independent } \\
\text { national bureau as part of the } \\
\text { Government of Armenia) } \\
\text { 2. Belgium (independent } \\
\text { national institute as part of } \\
\text { the Government of Belgium) } \\
\text { 3. Belarus (Independent } \\
\text { State Institution) } \\
\text { 4. Georgia (independent } \\
\text { national bureau as part of the } \\
\text { Government of Georgia) } \\
\text { 5. Latvia (independent na- } \\
\text { tional bureau as part of the } \\
\text { Government of Latvia) } \\
\text { 6. Romania (independent } \\
\text { national bureau as part of the } \\
\text { Government of Romania) }\end{array}$ \\
\hline
\end{tabular}

tioned laboratories, which have been organized organically within the police, there are other institutions (state) in the US that deal with expertise. A good example of this is the Bureau for Alcohol, Tobacco and Firearms and the Post Office Laboratory. Regarding the states created by the breakup of the SFR Yugoslavia, in 1904, the Unit for the Identification of Accused Persons for Crimes was defatted, and in 1929, the Criminalistic Institute was established at the University of Belgrade. After the end of the Second World War, the 50s and 60 s of the 20th century, Centers for Criminal Technique were established with all the Republic Ministries of Internal Affairs of the former SFR Yugoslavia. (Source A. B. Ivanović, A. R. Ivanović (2018) Forensics for lawyers). 


\begin{tabular}{|c|c|c|}
\hline $\begin{array}{l}\text { The countries of Europe } \\
\text { where forensic institutions } \\
\text { are part of the Ministry of } \\
\text { Internal Affairs (Police) }\end{array}$ & $\begin{array}{c}\text { The countries of Europe } \\
\text { where forensic } \\
\text { institutions are part of } \\
\text { the Ministry of Justice }\end{array}$ & $\begin{array}{l}\text { The countries of Europe } \\
\text { where forensic institutions } \\
\text { are part of other state } \\
\text { organizations }\end{array}$ \\
\hline $\begin{array}{l}\text { 17. Macedonia } \\
\text { 18. Moldova } \\
\text { 19. Germany } \\
\text { 20. Norway } \\
\text { 21. Poland } \\
\text { 22. The Czech Republic } \\
\text { 23. Romania } \\
\text { 24. Russian Federation } \\
\text { 25. Slovakia } \\
\text { 26. Slovenia } \\
\text { 27. Spain } \\
\text { 28. Serbia } \\
\text { 29. Sweden (by 2014, the } \\
\text { Swedish National Forensic } \\
\text { center was part of the } \\
\text { Ministry of Justice) } \\
\text { 30. Switzerland } \\
\text { 31. Turkey } \\
\text { 32. Ukraine } \\
\text { 33. United Kingdom }\end{array}$ & & $\begin{array}{l}\text { 7. France (Forensic Scien- } \\
\text { tific Institutes within the } \\
\text { French Gendarmerie) } \\
\text { 8. Italy (Forensic Scientific } \\
\text { Institutes within the Italian } \\
\text { Carabineers) } \\
\text { 9. Poland (Forensic Bu- } \\
\text { reau of the State Security } \\
\text { Agency), } \\
\text { 10. Turkey (Forensic Center } \\
\text { of the Gendarmerie of Tur- } \\
\text { key) }\end{array}$ \\
\hline
\end{tabular}

From Table 1, it can be seen that in the countries of Europe (in 33 countries), forensic institutions mostly and mainly were organized in the interior ministries (Police), further observation indicates that in 7 European countries, forensic institutions were organized in the ministries of justice (here it is important to mention that in some European countries, such as Lithuania, Russian Federation and Ukraine, forensic institutions exist both in the Ministry of Interior and in the Ministry of Justice), and eventually in 6 European countries, forensic institutions were organized under the jurisdiction of the Ministry of Interior, under the jurisdiction of the Ministry of Justice and exist as independent institutions of the governments of these countries (let us note that in addition to these organizational autonomous forensic institutions, there are also forensic institutions in the interior ministries of the aforementioned states in Georgia, Latvia and Romania). In further elaboration of the organization of forensic work in the countries of Europe, it is useful to mention that in some European countries, forensic institutions are positioned in higher education institutions - universities. Here is an example of university forensic laboratories, which are full members of ENFSI:

- Forensic Center at the Faculty of Forensic Science in Lausanne (Switzerland);

- Institute of Forensic Sciences at the Faculty of Legal Medicine - University of Istanbul; 
- Center for Forensic Science, Strathclyde University (UK);

- Institute for Forensic Research, University of Krakow (Poland).

Current problems in the positioning of Forensic Affairs in the European countries. As can be seen from the data presented in Table 1, forensic work in the countries of Europe is mostly and mainly done in police institutions. Using forensic analysis, testing and expertise in theory and practice give rise to doubts about this way of positioning forensic work. The basic complaint relates to how the institution (police) involved in filing criminal charges simultaneously supports these applications with forensic evidence that it provides! Often, during the main hearings in the presentation of evidence, a lawyer's complaint is heard in order to exclude forensic evidence obtained in police laboratories because the same authority (the police) is both the applicant for analysis (research, examination) and performs expert work (analysis, testing). It is useful here to mention a situation in practice that relates to the Forensic Institute in Tallinn (Estonia). Namely, in 2007, forensic affairs in Estonia were organized in the Ministry of Justice $^{1}$, respectively, the police forensic center and medical forensic bureaus were integrated into the Estonian Forensic Scientific Institute, organized in Ministry of Justice. However, several years later, the Estonian police for their needs hire forensics in the field of ballistics, dactyloscopy, mechanoscopy ... for practical and pragmatic reasons. Police authorities must have forensics in their composition because they have to support the forensic evidence ${ }^{2}$ in the pre-trial procedure, when collecting evidence for the purpose of filing criminal charges. What would be a proposal for overcoming the mentioned issues? The best way to both theoretically and practically remove suspicion about performing forensic work in the police is the accreditation of the police forensic laboratories themselves. This is because the accredited forensic laboratories are under constant expert supervision by the competent national accreditation institution. The European National Accreditation Institutions are members of the European Accreditation Cooperation ${ }^{3}$, which means that as long as they are in the process of accreditation (one accreditation is renewed every year, and every four years, the process is repeated, or re-accredited) police forensic laboratories are under expert supervision of the competent accreditation institution and the European Accreditation Cooperation. In this way, the theoretical and practical assurance is ensured by the integrity of forensic evidence obtained in forensic institutions that are organizationally positioned within the police.

Organizational positioning of Forensic Affairs in the Western Balkan countries. In the countries of the Western Balkans (those are the states that were created by the disintegration of Yugoslavia and Albania) forensic expert work is

1 Ivanović A., Rump M. (2011). Accreditation process forensic center of Montenegro to the mentoring of the European Union (Projects EMFA-2). 10th Symposium of Forensic Sciences. Bratislava. Symposium Journal.

2 Modly D. (2013). Some reasons that hinder the operational work of authorized officials of the organs of repression (police, prosecution, court). Annals of the Law Faculty of the University of Zenica. Issue No. 12. P. 23-51.

3 URL: http://www.european-accreditation.org/. 
carried out within the Ministries of the Interior or in the police' ${ }^{1}$. In Table 2, the basic data on organizational positioning of forensic institutions in the countries of the Western Balkans are presented.

Table 2

Basic data on state forensic institutions of the countries of the Western Balkans

\begin{tabular}{|c|c|c|c|}
\hline $\begin{array}{c}\text { The forensic } \\
\text { institution } \\
\text { and the state it } \\
\text { originates from }\end{array}$ & $\begin{array}{c}\text { Model of organizing } \\
\text { forensic institutions in the } \\
\text { Ministry of Internal } \\
\text { Affairs (police) }\end{array}$ & $\begin{array}{c}\text { Membership } \\
\text { in ENFSI }\end{array}$ & $\begin{array}{c}\text { Accreditation } \\
\text { status }\end{array}$ \\
\hline $\begin{array}{c}\text { National Forensic } \\
\text { Laboratory - Slovenia } \\
\text { unit within the General } \\
\text { Police Directorate, Ministry } \\
\text { of Internal Affairs }\end{array}$ & $\begin{array}{c}\text { Independent organizational member } \\
\text { since 1995 }\end{array}$ & $\begin{array}{c}\text { Accredited by } \\
\text { ISO 17025, } \\
2010\end{array}$ \\
\hline $\begin{array}{c}\text { Center for Forensic } \\
\text { Research, Testing and } \\
\text { Expertise "Ivan } \\
\text { Vučetić" - Croatia }\end{array}$ & $\begin{array}{c}\text { Independent organizational } \\
\text { unit within the Police } \\
\text { Directorate, Ministry } \\
\text { of Internal Affairs }\end{array}$ & $\begin{array}{c}\text { Full member } \\
\text { since 1998 }\end{array}$ & $\begin{array}{c}\text { Accredited by } \\
\text { ISO 17025, } \\
2010\end{array}$ \\
\hline $\begin{array}{c}\text { Agency for Forensic } \\
\text { Testing and } \\
\text { Expertise- Bosnia } \\
\text { and Herzegovina }\end{array}$ & $\begin{array}{c}\text { Independent organizational } \\
\text { unit within the Ministry } \\
\text { of Security of Bosnia } \\
\text { and Herzegovina }\end{array}$ & Not a member & Not accredited \\
\hline $\begin{array}{c}\text { Forensic Unit - } \\
\text { Criminalistic } \\
\text { Technical Center - } \\
\text { Bosnia and } \\
\text { Herzegovina } \\
\text { (Republic of Serbia) }\end{array}$ & $\begin{array}{c}\text { Part of the Police Support } \\
\text { Directorate, the Police, the } \\
\text { Ministry of the Interior of } \\
\text { the Republic of Serbia } \\
\text { and Herzegovina) }\end{array}$ & Not a member & Not accredited \\
\hline $\begin{array}{c}\text { Center for Forensic } \\
\text { and Infrared Support - }\end{array}$ & $\begin{array}{c}\text { Independent organizational } \\
\text { unit within the Federal } \\
\text { Police Administration, } \\
\text { Federal Ministry of the } \\
\text { Interior of Bosnia and } \\
\text { Herzegovina }\end{array}$ & Not a member & Not accredited \\
\hline
\end{tabular}

1 It is useful here to mention that forensic expertise is carried out in 17 institutions in Bosnia and Herzegovina. Namely, the state of Bosnia and Herzegovina consists of two entities (in whose Ministries of Interior there are forensic centers), and also have a statelevel forensic and expert agency, which is part of the State Ministry of Security. One of the two entities mentioned above, the Federation of Bosnia and Herzegovina, consists of ten cantons. In these cantons within their interior ministry, forensic laboratories exist. Furthermore, in the State of Bosnia and Herzegovina there is also one District (District Brčko). Also, the Interior Ministry of this District has its forensic laboratory. URL: https:// www.pravosudje.ba/vstv/faces/docservlet?p_id_doc $=21059$. 


\begin{tabular}{|c|c|c|c|}
\hline $\begin{array}{l}\text { The forensic } \\
\text { institution } \\
\text { and the state it } \\
\text { originates from }\end{array}$ & $\begin{array}{l}\text { Model of organizing } \\
\text { forensic institutions in the } \\
\text { Ministry of Internal } \\
\text { Affairs (police) }\end{array}$ & $\begin{array}{l}\text { Membership } \\
\text { in ENFSI }\end{array}$ & $\begin{array}{c}\text { Accreditation } \\
\text { status }\end{array}$ \\
\hline $\begin{array}{l}\text { National Criminal } \\
\text { Technical center - } \\
\text { Serbia }\end{array}$ & $\begin{array}{c}\text { Part of the Criminal Police } \\
\text { Directorate, Police } \\
\text { Directorate, Ministry of } \\
\text { Internal Affairs of Serbia }\end{array}$ & $\begin{array}{l}\text { Full member } \\
\text { since } 2009\end{array}$ & $\begin{array}{l}\text { Accredited by } \\
\text { ISO } 17025 \text {, } \\
2014\end{array}$ \\
\hline $\begin{array}{l}\text { Forensic center - } \\
\text { Montenegro }\end{array}$ & $\begin{array}{l}\text { Independent organizational } \\
\text { unit within the Police } \\
\text { Directorate, Ministry of } \\
\text { Interior of Montenegro }\end{array}$ & $\begin{array}{l}\text { Full member } \\
\text { since } 2009\end{array}$ & $\begin{array}{l}\text { Accredited by } \\
\text { ISO } 17025 \text {, } \\
2014\end{array}$ \\
\hline $\begin{array}{l}\text { Department of } \\
\text { Criminalistic } \\
\text { Technique - } \\
\text { Macedonia }\end{array}$ & $\begin{array}{l}\text { Part of the Public Security } \\
\text { Bureau, Ministry of Internal } \\
\text { Affairs of Macedonia }\end{array}$ & $\begin{array}{l}\text { Full member } \\
\text { since } 2014\end{array}$ & $\begin{array}{l}\text { Accredited by } \\
\text { ISO } 17025 \text {, } \\
2014\end{array}$ \\
\hline $\begin{array}{c}\text { Department of } \\
\text { Scientific Police - } \\
\text { Albania }\end{array}$ & $\begin{array}{c}\text { Independent organizational } \\
\text { unit within the State Police, } \\
\text { Ministry of Internal Affairs } \\
\text { Albania }\end{array}$ & Not a member & Not accredited \\
\hline
\end{tabular}

As mentioned above, in these countries, there are dilemmas and doubts about the fact that the work on proofing forensic evidence is carried out in the ministries of internal affairs, that is in the police. In order to eliminate the dilemma whether it is legally founded the task of establishing evidence through the forensic expertise is to use the decision of the Constitutional Court of Croatia in the police, as a body that files criminal charges.

Namely, the practice of regular courts in Croatia, as well as the Constitutional Court, met with objections by the lawyer that the evidence produced by the forensic expertise obtained at the Center for Forensic Expertise of the Croatian Ministry of the Interior ${ }^{1}$ was illegal because they were obtained in a forensic laboratory which is a part of the Ministry of Interior, and it (the Ministry) participates in the processing of criminal offenses and submits criminal charges! Furthermore, in addition to the lawyers' arguments, which seek the exclusion of the Center for Forensic Expertise of the Croatian Ministry of Internal Affairs, the forensic expert working on the examination of material traces from the scene of the criminal offense must not be employed in the same body as the prosecutor, the police officer, the defendant and damaged. The fact is that the Prosecutor's Office and the police (Ministry of the Interior) are in the same body (the government), which, in the opinion of some lawyers, is a sufficient reason for the exclu-

\footnotetext{
1 URL: http://www.forenzika.hr/DefaultCKV.aspx.
} 
sion of forensic staff from the center for Forensic Expertise of the Croatian Ministry of the Interior! The Constitutional Court of Croatia, in its opinion (response) on the remarks of individual lawyers, alleges that the center for Forensic Expertise of the Croatian Ministry of the Interior does not file criminal charges, but the Criminal Police is doing it. Furthermore, as the two most important segments of the opinion of the Constitutional Court to reject the defense of a lawyer, the following are stated ${ }^{1}$ :

1. Since 1998, the Center for Forensic Expertise of the Croatian Ministry of the Interior has been a full member of the European Association of Forensic Scientific Institutions (ENFSI) ${ }^{2}$. It is the umbrella organization of national forensic institutions that networks 68 forensic laboratories from 36 European countries. The ENFSI has been recognized by the European Union as an eminent association in the field of forensic science, which provides its members with the quality, development and implementation of forensic expertise.

2. The Center for Forensic Expertise of the Croatian Ministry of Internal Affairs has been accredited in accordance with the international standard ISO 17025. Obtaining the accreditation status means the fulfillment of all the requirements of the standard ISO 17025. Such as: development and application of complete documentation of the management system, development and application of written procedures for performance of expert methods, validation of expertise methods, calibration and regular monitoring of the correctness of all instruments, checking the skills of employed experts, conducting internal independent checks, managing with nonconforming work, participating in international laboratory tests, are only some of the demanding requirements of the ISO 17025 standard.

The final opinion of the Constitutional Court of Croatia regarding the complaints of individual lawyers was as follows: The legality of forensic expertise of the Center for Expertise of the Croatian Ministry of Internal Affairs, is not questioned by the existing legal argumentation since this expertise is organized organically in the Ministry of the Interior!

In 1998, in the Republic of Slovenia (which is a member of the European Union since $2004^{3}$ ), the Constitutional Court ruled that evidence obtained by forensic examination at the National Forensic Laboratory (hereinafter called as the Criminalistic Technical Center) of the Ministry of the Interior, cannot be recognized in court proceedings ${ }^{4}$ ! This decision of the Constitutional Court of Slovenia is explained by the fact that the National Forensic Laboratory organically belongs to the Ministry of the Interior, which is lawfully involved in the conduct of criminal investigations. For this reason, the evidence obtained at the

\footnotetext{
1 Legality of Evidence of the Center for Criminalistic Expertise "Ivan Vučetić". URL: http://iusinfo.com.hr/DailyContent/Topical.aspx?id=29266. croatia/.

URL: http://enfsi.eu/member/member-forensic-science-centre-ivan-vucetic-zagreb-

3 URL: https://europa.eu/european-union/about-eu/countries/member-countries/ slovenia en.

4 URL: http://odlocitve.us-rs.si/documents/e3/8d/u-i-132-952.pdf.
} 
National Forensic Laboratory would lose its process value. After this decision, forensic evidence obtained at the National Forensic Laboratory of the Ministry of Internal Affairs of Slovenia became usable only for the police, but not for the court! Experts from various state or private institutions or independent experts participate as forensic experts in court proceedings. It is not uncommon for forensic scientists from countries of the jurisdiction (of Italy, Croatia, Austria, etc.) to be hired in the courts of Slovenia. To date, the aforementioned decision of the Constitutional Court of Slovenia has not been changed and/or amended in some way. In continuation of the topic, here are a few examples of how the decision of the Constitutional Court of Slovenia that the examinations carried out in the Forensic Laboratory of the General Police Directorate of the Ministry of Internal Affairs cannot be evidence in court:

1. In one of the cases where the case was the criminal offense of Illicit Trafficking in Narcotic Drugs, the Defense attorney submitted an objection to the competent court that the findings of the experts engaged in the identification of the suspected drug cannot be accepted. The defense counsel argued that the experts who worked on the identification of the drug in question, employed by the Ministry of the Interior, who is also the applicant of the criminal complaint, and that because of this fact, the experts in this case could be biased. The lawyer also appealed to the decision of the Constitutional Court of Slovenia, that what was found by experts from the forensic laboratory of the General Police Directorate of the Ministry of Internal Affairs of Slovenia ${ }^{1}$, could not be evidence in court! However, the competent court that examined the appeal of a lawyer in this case (illicit drug trafficking) states that the experts of the Forensic Laboratory of the General Police Administration of the Ministry of Internal Affairs of Slovenia did not produce an opinion in this case (that is only the opinion of the expert witness), but for posterity the Police Directorate of Novo Mesto (town in Slovenia) conducted an analysis of an unknown substance, which was submitted to the police by the said Police Administration. Therefore, the analysis of the unknown substance, obtained in the Forensic Laboratory of the General Police Directorate of the Ministry of the Interior of Slovenia, according to the interpretation of the court, is a professional opinion, but not an expert opinion! It is further stated that the competent court in this case will approve the evaluation of this expert opinion, according to the Code of Criminal Procedure and thus does not act in contradiction with the decision of the Constitutional Court of Slovenia (which refers to the fact that the examination, research and analysis obtained in the forensic laboratory of the General Police Directorate of the Ministry of the Interior of Slovenia, do not be evidence in court). Finally, there was the conclusion decision of the court in charge of defense of the defense (the defendant's lawyer), that the forensic laboratory of the General Police Directorate of the Ministry of Internal Affairs of Slovenia cannot perform an expert review (in this case, of unknown substance suspected of being a narcotic drug), but it

1 National Forensic Laboratory. URL: https:/www.policija.si/index.php/component/ content/article/174-splono/9021-national-forenzini-laboratorij. 
can make an analysis, which does not mean that the said analysis could not be used as evidence in criminal proceedings. The court will proceed with the results of the analysis as well as with any other evidence in accordance with the principle of free assessment of evidence in the first instance of their objectivity and reliability.

2. In another case, the defense lawyer filed an objection challenging the conviction of the court against his client (defendant), because the same (court judgment) is based on the graphological evidence obtained in the Forensic Laboratory of the General Police Administration of the Ministry of the Interior of Slovenia. Namely, the client of the given lawyer was found guilty of the criminal offense of forging documents. The lawyer bases his complaint on the fact that the graphological examination of the driver's license (which was the subject of the criminal offense - forgery of documents) was carried out by the forensic laboratory of the General Police Directorate of the Ministry of Internal Affairs of Slovenia, and on the basis of the decision of the Constitutional Court of Slovenia, evidence obtained by laboratories of the General Police Directorate of the Ministry of the Interior of Slovenia are not evidence in the court, so the graphological expertise in question cannot be used as evidence in court! The reasoning of the lawyers regarding the bias of the expert witness, in this case is the same as in the previous case, which is stated in this paper. The lawyer also states in his complaint that his client (convicted) did not have the opportunity to engage another person (according to an attorney, an impartial expert), who will make the finding and opinion, and on that basis will declare whether the document (driver's license) is a forgery or original. According to the lawyer's complaint, the competent court replied that the court examines all the evidence of the procedure in the manner of determining objectivity and reliability in accordance with the principle of free assessment of evidence, so the evidence obtained in any institution is critically evaluated as any other evidence. Only the fact that the evidence was obtained by an expert working in a police forensic laboratory cannot be a reason for justified doubt about its validity and its exemption! The court will summon the expert witness (as well as everyone else) to the court at the main hearing in the courtroom and will conduct direct examination to determine his credibility. If after the direct examination of the expert witness at the main trial in the courtroom, there is no suspicion in his work, the findings and opinion of this expert witness will be accepted as evidence in the proceedings. In the present case, the court notes that during the hearing of an expert from the Forensic Laboratory of the General Police Directorate of the Ministry of Internal Affairs of Slovenia, the defense did not object or challenged the expert-graphological part of the expert's work, for this reason the court dismissed the defense's objection as unfounded.

3. Furthermore, in one case of rape and murder committed ${ }^{1}$ in the Republic of Slovenia, the Accused's lawyer filed an objection to the court. The objection is, inter alia, that the individual evidence submitted by the prosecutor against his

1 URL: http://www.sodisce.si/vsrs/odlocitve/23221/. 
client, obtained by research and examination in the Forensic Laboratory of the General Police Administration of the Ministry of the Interior of Slovenia. The complainant believes that the designation of a forensic laboratory by the General Police Directorate of the Ministry of Internal Affairs of Slovenia is an illegal mix of police and professional competencies. The Constitutional Court of Slovenia accepted the objection of the lawyer, but mostly because of some other violations of the legal provisions (police conduct during the search, poligraphic examination, detention, and other).

4. We also note the case of the abuse of firearms, in which the defense of the suspect filed an objection to the higher court instance, and the same was rejected by the Higher Court in Ljubljana (Republic of Slovenia)! Namely, in a criminal case, as an expert in the field of tracing firearms, an officer of the Forensic Laboratory of the General Police Administration of the Ministry of the Interior of Slovenia was engaged. The defense counsel filed an objection on the grounds that his findings and opinion should be discredited, because the expert is employed by a body (Ministry of Internal Affairs) who files a criminal complaint, and therefore is in conflict of interest! However, the High Court in Ljubljana (the Republic of Slovenia) made this objection unfounded. The explanation of the decision of the Higher Court is based on the fact that an expert witness employed by the Forensic Laboratory of the General Police Administration of the Ministry of Internal Affairs of Slovenia is also a registered court expert at the Ministry of Justice of the Republic of Slovenia. Furthermore, the explanation states that the expert did not undertake any actions in the form of interrogation of the suspect, the collection of evidence and/or any other operational action. He worked solely and exclusively on the processing of his material (material evidence) in the forensic laboratory. In conclusion of the decision of the High Court, it is stated that: Only the indication in the complaint that the expert is employed in the Forensic Laboratory of the General Police Directorate of the Ministry of Internal Affairs of Slovenia, but without submitting any concrete proposal, is not sufficient to exclude the expert from the case.

Conclusion. Forensic research, investigation and expert work is one of the most important, if not the most important, segments of all criminal crime investigations. The evidence obtained through forensic expertise must meet the requirements of science, profession, and, above all, such proof must exclude any kind of bias. As explained in the introduction of this paper, since the founding of forensic laboratories, organizational findings have been found in the Ministries of the Interior or in the police. Due to the fact that the police is a body that undertakes the task of investigating criminal offenses (investigation, examination) and ultimately submitting criminal charges against perpetrators of criminal acts, there has long been (not) justified objections to forensic evidence obtained at the Ministry of the Interior. For most of the countries in Europe, forensic laboratories are organized in the Ministry of the Interior (police). The decision to remove suspicions about the bias of evidence obtained in police forensic laboratories is

1 URL: http://sodisce.si/vislj/odlocitve/2015081111393052/. 
in the accreditation of forensic laboratories. The accredited forensic laboratory works under the permanent professional supervision of the competent accreditation body (the national accreditation body, which must be a member of the European Accreditation Cooperation). In the opinion of the author of this paper, thus (by accreditation of forensic laboratories), we can avoid every objection to the bias of evidence obtained in the Forensic Laboratory of the Interior Ministry (of Police)!

It is useful to mention in the end that, in 2015, the General Secretariat of the Council of Europe has issued a document: Creation of a European forensic science 2020 (Council conclusions on the vision for European Forensic Science 2020 including the creation of a European Forensic Science Area and the development of forensic science infrastructure in Europe $)^{1}$. Among other things, this document of the Council of Europe prescribes that by 2020, a register (list) of all institutions dealing with forensic expertise in Europe shall be established. For the purpose of implementing this task, the Director of the Forensic Institute of the Federal Criminal Police of the Germany in Wiesbaden, through the ENFSI (European Association of Forensic Scientific Institutions) $)^{2}$, sent his opinion on this proposal. In his response, he stated that in Germany the forensic expertise was carried out at the Federal Forensic Institute (Wiesbaden) and 16 provincial forensic laboratories. All of these forensic laboratories are part of the Provincial Police (Landeskriminalamt).

\section{ОРГАНІЗАЦІЯ СУДОВО-ЕКСПЕРТНИХ ЛАБОРАТОРІЙ У СВРОПІ СТОСОВНО ЗАХІДНИХ БАЛКАНСЬКИХ КРАЇН - ПРАКТИЧНИЙ АСПЕКТ}

\section{Іванович $A$.}

Проведено огляд організаційного розташування судових лабораторій у країнах Свропи з особливим акцентом на країни Західних Балкан. Це пов'язане з тим, що регіон Західних Балкан відносно невеликий, але на його території розташовується велика кількість краӥн, майже в усіх з яких організовані судово-експертні лабораторії. При иььму більшість судово-експертних лабораторій організовані при міністерствах внутрішніх справ, тобто в поліиії. Судові експертні дослідження є одним з найбільш важливих, якщяо не найважливішим сегментом усіх розслідувань кримінальних злочинів. Дані, отримані за допомогою судової експертизи, повинні відповідати вимогам науки, професії експерта, і насамперед такі докази мають виключати будь-яке упереджене ставлення. Із моменту створення судово-експертних лабораторій організаційно вони перебували в міністерствах внутрішніх справ або в полічії. У зв'язку з тим, щзо полічія є органом, на який покладено завдання розслідування карних злочинів (проведення розслідування, експертиз) і в остаточному підсумку надає кримінальні обвинувачення (докази) стосовно осіб, щзо вчинили злочинні діяння, то вже давно висуваються обтрунтовані (і необтрун-

1 URL: https://www.consilium.europa.eu/uedocs/cms_data/docs/pressdata/en/ jha/126875.pdf.

2 URL: http://enfsi.eu/. 
товані) заперечення проти судових доказів, отриманих в експертних лабораторіях Міністерства внутрішніх справ. Рішення про усунення підозр шчодо упередженості доказів, отриманих у поліцейських судово-експертних лабораторіях, полягає, на думку автора, у проведенні їх акредитації. Акредитована судово-експертна лабораторія працює під постійним професійним наглядом компетентного органу з акредитації (національного органу з акредитації, який повинен бути членом Європейської кооперації з акредитаціï). У такий спосіб (шляхом акредитачії судових лабораторій) можна уникнути будь-яких заперечень проти упередженості доказів, отриманих у судово-експертних лабораторіях міністерств внутрішніх справ (поліиіi).

Ключові слова: судово-експертна лабораторія, полічія, акредитачія.

\section{ОРГАНИЗАЦИЯ СУДЕБНО-ЭКСПЕРТНЫХ ЛАБОРАТОРИЙ В ЕВРОПЕ ПРИМЕНИТЕЛЬНО К ЗАПАДНЫМ БАЛКАНСКИМ СТРАНАМ - ПРАКТИЧЕСКИЙ АСПЕКТ}

\section{Иванович А.}

Представлен обзор организационного расположения судебных лабораторий в странах Европы с особым акцентом на страны Западных Балкан. Это связано с тем, что регион Западных Балкан относительно невелик, но на его территории находится большое количество стран, почти во всех из которых организованы судебно-экспертные лаборатории. При этом большинство судебно-экспертных лабораторий организованы при министерствах внутренних дел, то есть в полиции. Судебные экспертные исследования являются одним из наиболее важных, если не самым важным сегментом всех расследований уголовных преступлений. Данные, полученные с помощьью судебной экспертизы, должны соответствовать требованиям науки, профессии эксперта, и, прежде всего, такие доказательства должны исключать любое предвзятое отночение. Смомента создания судебноэкспертных лабораторий организационно они находились в министерствах внутренних дел или в полиции. В связи с тем, что полиция является органом, на который возложена задача расследования уголовных преступлений (проведение расследования, экспертиз) и в конечном итоге предоставляет уголовные обвинения (доказательства) в отношении лии, совершивших преступные деяния, то уже давно выдвигаются обоснованные (и необоснованные) возражения против судебных доказательств, полученных в экспертных лабораториях Министерства внутренних дел. Решение об устранении подозрений относительно предвзятости доказательств, полученных в полицейских судебно-экспертных лабораториях, заключается, по мнению автора, в проведении их аккредитации. Аккредитованная судебно-экспертная лаборатория работает под постоянным профессиональным надзором компетентного органа по аккредитации (национального органа по аккредитации, который должен быть членом Европейской кооперации по аккредитации). Таким образом (путем аккредитации судебных лабораторий), можно избежать любых возражений против предвзятости доказательств, полученных в судебно-экспертных лабораториях министерств внутренних дел (полиции).

Ключевые слова: судебно-экспертная лаборатория, полищия, аккредитация. 